\title{
Signet-ring stromal tumor of the ovary: an extremely rare neoplasm
}

\section{Overin signet-ring stromal tümörü: Çok nadir bir neoplazm}

\author{
Yavuz Emre Şükür, Batuhan Özmen, Cem Somer Atabekoğlu, Murat Sönmezer, Firat Ortaç \\ Department of Obstetrics and Gynecology, School of Medicine, Ankara University, Ankara, Trukey
}

\section{Abstract}

Signet-ring stromal tumor (SRST) of the ovary is an extremely rare neoplasm. Herein, we present a SRST of the ovary, which is the twelfth report in the literature. A 44 year-old, G4P2 patient was admitted with the complaint of polymenorrhea. She was operated on for persistent semisolid ovarian mass measuring $5 \mathrm{~cm}$ in diameter. The pathological examination confirmed the diagnosis of a benign ovarian SRST. In conclusion, SRST is an extremely rare benign ovarian tumor with good prognosis according to the current literature. Although the recurrence rate or malignant transformation potential of these tumors are not yet known, close follow-up in the post-operative period may be beneficial. (J Turkish-German Gynecol Assoc 2011; 12: 59-60)

Key words: Signet-ring stromal tumor, ovary

Received: 26 April, 2010

Accepted: 21 June, 2010

\section{Introduction}

Signet-ring stromal tumor (SRST) of the ovary, first reported by Ramzy in 1976, is an extremely rare neoplasm (1). The Ovarian SRSTs are currently classified as sex cord stromal ovarian tumors within the spectrum of thecoma-fibromas, and are non-functioning distinctive stromal tumors characterized by the proliferation of stroma and signet-ring cell appearance due to the cytoplasmic vacuoles $(2,3)$. Herein, we present a SRST of the ovary which is the twelfth reported case in the literature.

\section{Case}

A 44 year-old, G4 P2 patient was admitted to the out-patients clinic with the complaint of polymenorrhea for 3 months. Her medical history revealed total thyroidectomy and subsequent levo-thyroxine sodium replacement. Her bimanual gynecologic examination revealed a firm, mobile and fine contoured right adnexal mass approximately $5 \mathrm{~cm}$ in diameter. Transvaginal ultrasound confirmed a 48x45 mm, semisolid mass with heterogeneous echogenity in the right ovary. The basal serum levels of tumor markers including CA 125, CA 15-3, CA 19-9, CEA, 3 hCG, AFP, LDH, and inhibin were all within the normal ranges. Monthly follow-up was chosen by

\section{Özet}

Ovaryen signet-ring stromal tümör (SRST) çok nadir karşllaşlan bir neoplazmdır. Bu makalede, literatürdeki onikinci ovaryen SRST vakası sunulmuştur. 44 yaşında G4P2 olan hasta polimenore şikayeti ile başvurdu. Hasta $5 \mathrm{~cm}$ çapında persistan semisolid ovaryen kitle nedeniyle opere edildi ve patolojik inceleme ile benign ovaryen SRST tanıSı koyuldu. Sonuç olarak, SRST overin çok nadir görülen ve mevcut literatüre göre iyi prognoza sahip bir tümörüdür. Ancak tekrarlama sıklığı veya malign dönüşüm potansiyeli henüz bilinmediğinden postoperatif dönemde bu hastaların yakın takip edilmesi faydalı olacaktır.

(J Turkish-German Gynecol Assoc 2011; 12: 59-60)

Anahtar kelimeler: Signet-ring stromal tümör, over

Geliş Tarihi: 26 Nisan 2010

Kabul Tarihi: 21 Haziran 2010

the patient after a detailed informed consent concerning the management of adnexal mass in the perimenopausal period. Operation for histological diagnosis of the mass was recommended to the patient after two months of persistence with neither a change in the diameter nor appearance. A right ovarian semisolid mass measuring about $5 \mathrm{~cm}$ was identified via laparotomy by Pfannenstiel incision with regard to the patient's preferred operation route (Figure 1). Except for the right ovary, all other pelvic and abdominal organs appeared to be normal. Right salphingo-oopherectomy was then performed and as the frozen-section revealed a benign ovarian neoplasm, the operation was terminated. The pathological examination of the operation specimen indicated signet ring cells with benign appearance and confirmed the diagnosis of a benign ovarian SRST. The patient was uneventfully discharged on the $3^{\text {rd }}$ post-operative day.

\section{Pathological findings}

Microscopically, the tumor was composed of a diffuse growth of vacuolated cells without cellular atypia or mitotic figures. Cells with fully developed vacuoles exhibited eccentric, crescent-shaped hyperchromatic nuclei. The vacuoles of tumor cells were negative for PAS reaction. Intracytoplasmic hyaline globules were positive for PAS reaction. Mucin staining was negative in the signet-ring cells. The signet-ring cells were intensely positive for vimentin. Staining with inhibin and SMA 


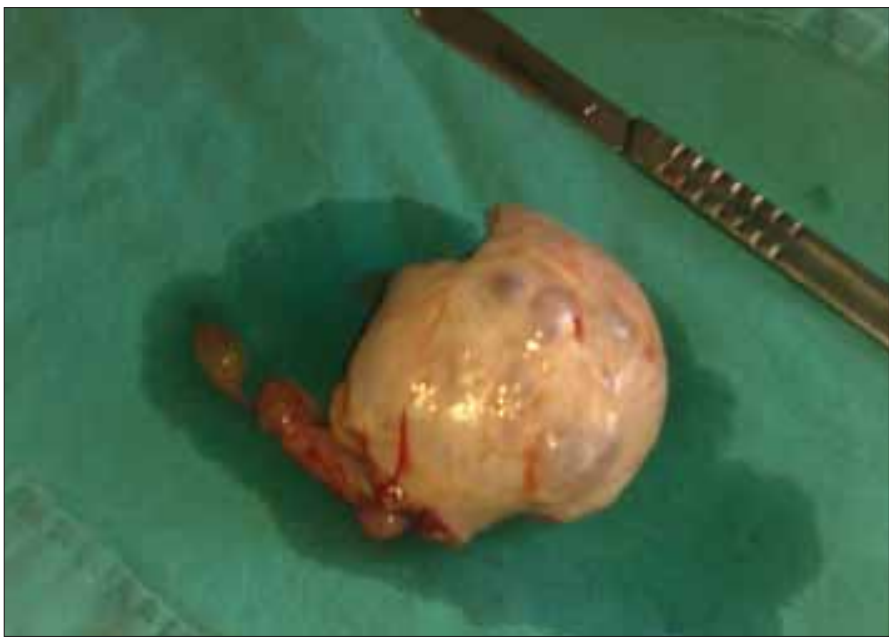

Figure 1. White-grayish, brilliant tumor and right ovary approximately $5 \mathrm{~cm}$ in diameter

were also focally positive. However, calretinin, CK7, CK20 and PAN cytokeratin were negative.

\section{Discussion}

There were only eleven reported cases in the literature in which unilaterality has been reported only in the present case. There is a considerable variation in the largest diameter ranging from 2.5 to $13 \mathrm{~cm}$. The mean age of the patients was 52 years, ranging from 21 to 83 years (4). The most frequent symptom was abdominal pain in contrast to the present case and almost all of the tumors showed a solid appearance under ultrasonographic assessment (5).

The presence of non-lipid signet-ring cells admixed with fibromatous areas is the main microscopic feature of SRSTs, differentiating from other ovarian sex cord stromal tumors $(3,5)$. Hyaline globules are present in some tumors and ultrastructural examination revealed the globules to be degenerating erythrocytes, many of which had been phagocytosed by the tumor cells (ult). Stains for lipid and mucin are negative (3).

SRST of the ovary is a distinct type of stromal neoplasm that can mimic Krukenberg tumors. A negative history of carcinoma is not reliable in the distinction of SRST from Krukenberg tumor, as only a minority of patients with Krukenberg tumor have a history of carcinoma (6). Both these tumors may show multinodularity, hemorrhage, and necrosis (6). Although neither nuclear atypia nor mitotic activity is helpful in distinguishing between these tumors, there are histological differences that can be evaluated on hematoxylene-eosin sections. Furthermore, these differences are especially valuable on frozen section. The presence of glandular structures or nests supports an epithelial differentiation (Krukenberg tumor). An additional subtle difference is that the cytoplasm of the signet-ring cells in SRST is white and appears "empty" whereas the cytoplasm of the Krukenberg tumor's signet-ring cells is characteristically pale and occasionally granular and eosinophilic (7). All the SRSTs are negative for PAS-D and mucicarmine, whereas the signetring cell component is positive in all the cases of Krukenberg tumor $(6,7)$. Pancytokeratin is a very useful marker with no expression in the SRSTs but with consistent staining of Krukenberg tumors $(6,7)$. Vimentin is also helpful in separating the two lesions, with positivity in SRSTs.

In the clinical perspective, management of an ovarian neoplasm highly depends on the incidence, rate of persistence, regression, recurrence, malignant transformation, as well as the metastatic potential. Thus, because of insufficient data the management of ovarian SRSTs is critically unknown and still obscure. Due to their theoretical regression potential, SRSTs may frequently be undiagnosed in asymptomatic cases or misdiagnosed as other benign ovarian masses (ie; haemorrhagic cysts) in symptomatic cases with smaller tumors $(<5 \mathrm{~cm}$ in diameter). Although an aggressive pattern has not yet been reported, it is vitally important to determine whether SRSTs have risk of malignant transformation, recurrence or metastasis. In regard to the possible regression potential, expectant management is an acceptable approach for such tumors, especially when the size is $<5 \mathrm{~cm}$. However, the current management of SRSTs with a diameter 5 to $10 \mathrm{~cm}$ is critically controversial: extensive surgical excision is more commonly performed compared to other persistent ovarian tumors.

In conclusion, SRST is an extremely rare benign ovarian tumor with good prognosis according to the current literature, and these tumors may be misdiagnosed as Krukenberg tumors or haemorrhagic cysts. Clinical, operative and histological findings with immunohistochemical and mucin stains are useful for diagnosis. Since the recurrence rate or malignant transformation potential of SRSTs of the ovary are not yet known, close follow-up may be beneficial in the post-operative period.

\section{Conflict of interest}

None declared.

\section{References}

1. Ramzy I. Signet-ring stromal tumor of the ovary. Histochemical, light, and electron microscopic study. Cancer 1976; 38: 166-72. [CrossRef]

2. Matsumoto M, Hayashi Y, Ohtsuki Y, Ikegami N, Toi M, Iguchi M et al. Signet-ring stromal tumor of the ovary: an immunohistochemical and ultrastructural study with a review of the literature. Med Mol Morphol 2008; 41: 165-70. [CrossRef]

3. Dickersin GR, Young RH, Scully RE. Signet-ring stromal and related tumors of the ovary. Ultrastruct Pathol 1995; 19: 401-19. [CrossRef]

4. Su RM, Chang KC, Chou CY. Signet-ring stromal tumor of the ovary: A case report. Int J Gynecol Cancer 2003; 13: 90-3. [CrossRef]

5. Hardisson D, Regojo RM, Marino-Enriquez A, Martinez-Garcia M. Signet-ring stromal tumor of the ovary: Report of a case and review of the literature. Pathol Oncol Res 2008; 14: 333-6. [CrossRef]

6. Vang R, Bague S, Tavassoli FA, Prat J. Signet-ring stromal tumor of the ovary: clinicopathological analysis and comparison with Krukenberg tumor. Int J Gynecol Pathol 2004; 23: 45-51. [CrossRef]

7. Young RE, Scully RE. Metastatic tumors of the ovary. In: Kurman RJ, ed. Blaustein's Pathology of the Female Genital Tract. 5th ed. New York, NY: Springer; 2002; 1063-101. 